Психолого-педагогічні проблеми становлення сучасного фахівця Випуск 2018

УДК 37.015.31-027.1:331.548:159.923.2(331.108.6)"2017"

DOI 10.26697/9786177089017.2018.245

\author{
Нестеренко Альона Сергіївна \\ Державний вищий навчальний заклад \\ «Донбаський державний педагогічний університет»

\section{ОСОБЛИВОСТІ РОЗВИТКУ ОСОБИСТОСТІ УЧНЯ НА ЗАНЯТТЯХ ТРУДОВОГО НАВЧАННЯ ЗА ОНОВЛЕНОЮ ПРОГРАМОЮ 2017 р.}

(C) Нестеренко А. С., 2018

Висвітлено особливості формування особистості учня на заняттях трудового навчання за оновленою програмою 2017 року на основі компетентнісного та особистісно-орієнтованого підходу. Розглянуто розвиток особистості учня на основі 10 ключових компетентностей, передбачених оновленою навчальною програмою, які спрямовані формуванню життєвої компетентності учнів. Наголочено на провідній проектно-технологічній компетентності в трудовому навчанні, яка характеризується здатністю учня застосовувати знання, уміння, навички в процесі виготовлення запланованого проекту. Проаналізовано зміни в змісті оновленої навчальної програми з трудового навчання в умовах Нової української школи, які сприяють підготовиі випускника основної школи до самостійності, підприємливості, ініціативності, творчості, саморозвитку та самонавчання.

Ключові слова: особистість, особистісна спрямованість навчання, компетентність, трудове навчання, оновлена навчальна програма.

Проблема, її зв'язок із важливими науковими чи практичними завданнями. Входження України до Європейського освітнього та наукового простору передбачає оновлення змісту освіти та потребує нових підходів до розв'язання проблем становлення i розвитку особистості, обумовлює необхідність докорінного переосмислення освітньої парадигми, актуалізації змісту навчання, технології становлення особистості, як суб'єкта і проектувальника життя. Тобто пріоритетним напрямком державної політики в сучасній освіті стає їі особистісна орієнтація на учня. Що й сприяло до оновлення освітніх навчальних програм.

Трудове навчання не стало виключенням: так від 07.06.2017 р. № 804 Міністерством освіти і науки України затверджена оновлена навчальна програма 3 трудового навчання в 5-9 класах. Програма спрямована на розвиток особистості шляхом залучення учнів на уроках трудового навчання до проектної діяльності як провідного 


\section{Збірник наукових статей}

засобу розвитку та навчання, формування в них здатності до самостійного навчання, оволодіння сучасними засобами технологій та вміння конструювати власний процес пізнання i на практиці реалізувати заплановане.

Аналіз публікацій (виділення невирішених проблем). Проблемами розвитку особистості учня займались такі вчені, як I. Бех, I. Зязюн, С. Подмазін, О. Пєхота, В. Рибалка, В. Сериков, С. Сисоєва, М. Чобітько, І. Якиманська та інші. Особливості розвитку особистості учня на уроках трудового навчання розглядали: С. Борисова, О. Коберник, В. Мадзігон, А. Терещук, А. Цина, А. Цідило та інші. В ïх працях розкрито шляхи розвитку особистості учня та підготовки вчителя до формування особистості учня. Впроваджена в навчальний процес оновлена програма трудового навчання для 5-9 та 10-11 класів [3] детально визначає нові можливості розвитку особистості учня на уроках трудового навчання. Такі можливості викладені в рекомендаціях Н. Боринець, М. Компанієць, О. Захар, О. Рукінов, О. Трибухіна та інших. Ці можливості визначають певні особливості організації освітнього процесу на уроках трудового навчання. Розкриємо їх.

Ціль статті - розкрити особливості формування особистості учня на заняттях трудового навчання на основі оновленої навчальної програми.

Виклад основного матеріалу, обгрунтування результатів дослідження. Нова парадигма освіти базується на компетентнісному підході, який визначає розвиток особистості учня, на основі його індивідуальної траєкторії розвитку. Відповідно до Закону України «Про освіту», Концепції Нової української школи, запровадження в освітній процес оновленої навчальної програми 3 трудового навчання для 5-9 класів здійснюється через $[3 ; 4 ; 6]$ :

- всебічний розвиток та соціалізацію учнів, формування їхньої національної самосвідомості, загальної культури, світоглядних орієнтирів, екологічного стилю мислення і поведінки; розвиток творчих здібностей, дослідницьких і життєзабезпечувальних навичок, здатності до саморозвитку й самонавчання в умовах глобальних змін і викликів;

- формування здатності до самостійного навчання, оволодіння засобами сучасних технологій, умінь конструювати власний процес пізнання і на практиці реалізувати заплановане;

- підготовку випускника основної школи, здатного до самостійності, творчості, підприємливості та ініціативності, розвиток особистості, яка має уявлення про світобудову, бережно ставиться до природи, безпечно й доцільно використовує досягнення науки i техніки, дотримується здорового способу життя. 
Як зазначають Н. Боринець, С. Дятленко та інші педагоги, зміст оновленої навчальної програми 3 трудового навчання орієнтовано на формування в учнів ключових та предметних компетентностей, які покликані наблизити процес трудового навчання до життєвих потреб учня, його інтересів і природних здібностей [3, с. 4].

Згідно 3 вимогами Нової української школи за оновленою навчальною програмою формування особистості учня на уроках трудового навчання базується на основі таких 10 ключових компетентностей: спілкування державною мовою (і у разі відмінності) мовами; спілкування іноземними мовами; математична компетентність; основні компетентності у природничих науках i технологіях; інформаційно-цифрова компетентність; уміння вчитися впродовж життя; ініціативність і підприємливість; соціальна та громадянська компетентності; обізнаність і самовираження у сфері культури; екологічна грамотність і здорове життя [3, с. 4-6]. Провідною предметною компетентністю є предметно-технологічна, яка характеризується здатністю учня застосовувати знання, уміння, навички в процесі проектно-технологічної діяльності для виготовлення виробу (або надання послуги) від творчого задуму до його втілення в готовий продукт (послугу) за обраною технологією [2, с. 13].

Згідно 3 оновленою програмою, ключові i предметні компетентності у трудовому навчанні передбачають формування в учнів здатності до: формування власної потреби в навчанні, допитливості, прагненню пізнавати нове, підприємницької діяльності, толерантності, вміння працювати в команді, приймати рішення та вибирати свою траєкторію навчання згідно своїх нахилів та матеріально-технічних можливостей майстерні, а також здатність до генерування нових ідей та розвиток ініціативи втілювати їх у життя для підвищення власного добробуту і для розвитку суспільства [3].

Всі ці компетентності в цілому і дають можливість підготувати всебічно-розвинену особистість, яка буде здатна вміло орієнтуватись в інформаційно-цифровій, соціальній, культурній сфері, розвивати підприємницьку, екологічну грамотність та ін.

Н. І. Боринець визначає такі особливості оновленої програми 3 трудового навчання [9, с. 6-7]:

- зміст програми орієнтує на формування ключових i предметних компетентностей;

- наскрізними змістовними лініями програми є: екологічна безпека, громадянська відповідальність, здоров'я і безпека, підприємливість і фінансова грамотність;

- проектно-технологічна діяльність учнів визначає зміст навчання; 


\section{Збірник наукових статей}

- формування змісту технологічної діяльності здійснюється на основі об'єктів проектної діяльності, а не технологій;

- зміст програмового матеріалу, як такий, відсутній;

- програма забезпечує можливість навчання учнів у змішаних класах (дівчат і хлопців) різних технологій на одному уроці за умови виконання проекту за спільною темою;

- достатньо високий рівень академічної свободи вчителя;

- програма орієнтована на інтелектуальний розвиток учня.

Таким чином, оновлена програма 3 трудового навчання для учнів 5-9 класів відрізняється від попередніх програм тим, що вона має особливу структуру та зміст і передбачає використання нових підходів при викладанні навчального предмету. Програми, за якими викладався предмет у минулих роках, мали таку структуру: пояснювальна, записка, тематичний план, обов'язкова складова (блоки за класами), варіативна складова, в яких вказувалось кількість годин, зміст навчального матеріалу, державні вимоги до рівня загальної підготовки учня. Структура оновленої програми включає в себе пояснювальну записку і зміст, який поданий за такою формою: очікувані результати навчально-пізнавальної діяльності учнів; орієнтовний перелік об'єктів проектно-технологічної діяльності учнів; перелік основних технологій. Провідним завданням учителя $\epsilon$ реалізація очікуваних результатів. Такими результатами є: знання, діяльність, цінності.

Основними відмінними характеристиками програми $є$ : застосування компетентністного та особистісно-орієнтованого підходів при викладанні навчального предмету; максимальне впровадження проектного методу; застосування інноваційних технологій; врахування можливостей матеріально-технічної бази шкільної майстерні; надання вчителеві більше автономії при викладанні навчального предмету; відсутність жорсткої регламентації часу при плануванні навчальних проектів, що дозволяє вчителю й учням більш творчо обирати вид практичної роботи; побудову навчального процесу на педагогіці партнерства між вчителем, учнем i батьками, а також побудову навчального проекту на основі індивідуальної траєкторії розвитку дитини. Все це сприяє гармонійному та всебічному розвитку особистості учня.

Разом 3 тим, слід відзначити, що групою педагогів під керівництвом М. Компанієць у складі О. Захар, О. Трибухіна, О. Ракінова та інших розроблено методичні рекомендації до викладання трудового навчання, в яких визначено основні напрями діяльності учнів і вчителів на уроках трудового навчання за новим змістом. До них віднесено такі напрями [8, с. 4]:

- систематичне використання в роботі 3 учнями матеріальнотехнічної бази майстерні; 
- формування у школярів психологічної, етичної та практичної готовності до праці;

- формування трудових навичок i вмінь, технічних, технологічних, конструкторських i первинних економічних знань, необхідних для участі в суспільно-корисній, продуктивній праці;

- застосування знань з основ наук у трудовій діяльності;

- розширення й поглиблення політехнічного кругозору учнів, ознайомлення їx iз загальними науковими основами та єдиними організаційно-економічними принципами сучасного виробництва;

- ознайомлення 3 масовими робочими професіями, формування стійких інтересів до певних видів праці, спонукання до свідомого вибору професії та отримання первинної професійної підготовки.

Згідно 3 названими напрямами, як вказують викладачі методичних рекомендацій, вчитель матиме змогу розвивати особистість учня не за жорстко встановленим планом, як це було раніше, а відповідно до можливостей шкільної майстерні, здібностей учнів, їхнього професійного спрямування, розвиваючи здатність до самонавчання та саморозвитку. Відповідно до Концепції Нової української школи виконуючи нову роль - не як єдиного наставника та джерела знань, а як коучера, фасилітатора, тьютора, модератора в індивідуальній освітній траєкторії дитини [4, с. 18].

В оновленій програмі наголошується, що основні зміни змісту трудового навчання пов'язані 3 тим, щоб посилити його сильні сторони, які водночас, не $є$ чимось новим для вчителів трудового навчання. Такою «сильною стороною» $\epsilon$ метод проектів, який у попередній програмі поєднували із застарілими принципами побудови змісту освіти, що не дозволяло повною мірою реалізувати переваги цієї інновації. Для повноцінного запровадження проектної технології в змісті трудового навчання відсутня жорстка регламентація навчального часу, вчителю дозволено більш творчо обирати вид практичної діяльності, об’єкт проектування, матеріали і технології для реалізації проекту - конструювати навчальний процес, який буде значимим у першу чергу для учнів [1, с. 2]. Розвиток особистості учня в Новій українській школі на заняттях з трудового навчання базується на основі методу проектів.

Адже, трудове навчання - це навчальний предмет, який цілком заснований на перетворювальній наочно-практичній діяльності учнів, яку пов'язують 3 проектно-технологічною компетенцією. За оновленою навчальною програмою проектно-технологічна компетентність і $є$ основою розвитку особистості учня на заняттях трудового навчання. Проектна компетентність передбачає складання відповідного комплексу документів (проектів) з виготовлення певного виробу, а сам процес його виготовлення забезпечується технологічною 


\section{Збірник наукових статей}

компетентністю Результатом проектно-технологічної діяльності учнів визначено проект - спроектований i виготовлений виріб чи послуга [2, с. 4].

Вчені, зокрема О. М. Коберник та А. І. Терещук, розглядали метод проектів як засіб реалізації особистісно-орієнтованої парадигми трудової підготовки учнів, який дозволяє активно розвивати в учнів основні види мислення, творчі здібності, прагнення самому творити, усвідомити себе творцем під час роботи 3 «неслухняними інструментами», «розумними конструкціями», «технологічними системами» тощо. В учнів повинна виробитись і закріпитись звичка до аналізу споживчих, економічних, екологічних i технологічних ситуацій, здатність оцінювати ідеї, виходячи з реальних потреб, матеріальних можливостей і вміти вибирати найбільш технологічний спосіб виготовлення об'єкта проектної діяльності, який відповідав би вимогам дизайну [10, с. $11 ; 12]$.

Як стверджує О. М. Коберник, запроваджений нині проектнотехнологічний підхід на уроках трудового навчання $є$ однією з умов розвитку особистості учня, яка вимагає оволодіння такими знаннями i навичками, як аналіз поставленого проектного завдання; проектування обраного виробу, конструювання та виготовлення виробів відповідно до освітньої програми 3 попереднім техніко-технологічним обгрунтуванням конструкцій, художньо-естетичним оздобленням виробів, практичним випробуванням технічного устаткування, дизайну виробів, виконанням і використанням необхідних графічних ескізів, креслень, технічних малюнків, макетів; виріб навчального матеріалу, що передбачає формуванню системи техніко-технічних знань, розвиток регіонального декоративно-ужиткового мистецтва, народних ремесл і промислів, технічно творчості [7, с. 5].

Відповідно до оновленої навчальної програми у 5-6 класах учні виконують 6-10 проектів, у 7-8 класах опановують від 4 до 6 проектів, а у 9 класі - 2 проекти (плюс 2 проекти 3 технології побутової діяльності та самообслуговування в 5-8 класах та 1 проект у 9 класі). Зменшення кількості проектів зумовлене кількістю годин, відведених на вивчення предмета в різних класах, і потребою в ускладненні виробів та технологій. У 5-6 класах учні хочуть швидко побачити свої результати, тому й проекти мають бути простішими й не вимагати багато часу. У 7-8 класах проекти вже дещо складніші, але вимагають більшої самостійності при їх виконанні. В 9 класі виконання проекту передбачає врахування вже засвоєних знань, вмінь та навичок, навчальна цінність полягає в комплексному поєднанні технологій. Виконання запланованих проектів сприяє формуванню особистості учнів протягом усього терміну навчання [2, с. 4-5]. 
Психолого-педагогічні проблеми становлення сучасного фахівця Випуск 2018

Суттєве місце в інтелектуальному розвитку дитини за оновленою програмою забезпечується проектно-технологічною діяльністю, що характеризується високою загальною та спеціальною освіченістю, широким колом і системністю знань про виробництво й природу, культурою розумової праці, умінням користуватися своїми знаннями, застосовувати їх у своїй практичній діяльності. Він виявляється в загальних i спеціальних здібностях: допитливості, прагненні до здобуття й збагачення знань, умінні самостійно вирішувати нові пізнавальні й трудові завдання, задовольняти свої пізнавальні інтереси, систематизувати здобуті знання. Його ефективність та рівень розвитку залежить від: змісту, методів, засобів і способів організації процесу навчання й виховання; внутрішньої структури методів навчання, від прийомів активізації пізнавальної і трудової діяльності учнів, від змісту й характеру завдань і способів їх виконання. Репродуктивні завдання менше сприяють розумовому розвитку, ніж евристичні, творчі.

У процесі проектно-технологічної діяльності також здійснюється розвиток самостійності школярів, який забезпечується через таку послідовність: формування вмінь працювати за зразком i вказівками вчителя та технологічною документацією; навчання працювати 3 коментуванням своїх дій; формування вмінь самостійно застосовувати креслення або технологічну карту тощо.

Так, у 5 класі навчальною програмою (технічні види праці) передбачено виконання 6 проектів: (з деревинних матеріалів, на основі технології обробки деревини та ажурного випилювання. Навчальний процес хлопчиків за цією програмою передбачає розвиток інтелектуальних, емоційно-вольових компонентів розвитку особистості, а також адаптацію п’ятикласників до нових умов навчання (зміна вчителя, кабінетна система навчання).

3 обслуговуючих видів праці в 5 класі передбачено виконання 8 проектів: гольниця, м'яка пласка іграшка, серветка, панно, прикраса 3 бісеру, брелок, торбинка для дрібничок, лялька-мотанка виконаних технологією виготовлення вишитих виробів, технологією обробки текстильних та природних матеріалів ручним і машинним способом, виготовлення виробів з бісеру. По 2 проекти (як для хлопчиків, так i для дівчаток) 3 технології побутової діяльності та самообслуговування: «Сервірування святкового столу» та «Побутові електроприлади в моєму житті». Всі ці проекти передбачають розвиток особистості учня, визначення пріоритетів розвитку його індивідуальності, неповторності, самобутності при цьому «включення» в процес становлення на професійних та життєвий шлях i виховання бережливого ставлення до свого здоров'я та до здоров'я інших 


\section{Збірник наукових статей}

працюючи 3 різними інструментами та матеріалами, що $\epsilon$ дуже важливим у процесі трудового навчання.

Починаючи 35 класу, діти вибирають проекти, керуючись настановами вчителя, виконують технологічні операції відповідно до обраного виробу та технології його виготовлення, дотримуватись прийомів роботи 3 інструментами та пристосуваннями, визначають необхідну кількість матеріалів для його виготовлення, а також включаючи весь інтелектуальний потенціал (психічні процеси, здібності, задатки), розвиваючи фантазію, та практичні вміння роботи 3 природним матеріалом. При цьому розвиваючи моторику рук, уважність, мислення, пам'ять, уяву, формування характеру та виховання поважливого ставлення до людей різних видів праці. Активне застосування методу проекту на заняттях трудового навчання в 5-9 класах передбачає формування в учнів таких якостей, як згуртованість учнівського колективу, прояв ініціативи учнів, виявлення та розкриття талантів учня.

У 5 класі учні адаптуються до середньої школи; у них розвивається пізнавальна сфера, зацікавленість у вивченні трудового навчання. У 6 класі розвиток особистості школяра продовжується, але набуває своїх особливостей у зв'язку з адаптованістю учнів до нових умов навчання. Так, учні вже ознайомлені 3 правилами роботи в навчальній майстерні, знають правила безпечної праці та організацію робочого місця, вміють працювати 3 інструкційними картками, інструментами та матеріалами, а також розуміють особливості проектно-технологічної діяльності.

Новим у роботі учнів $є$ те, що вони навчаються планувати власну проектну діяльність, виконувати технологічні операції відповідно до обраного виробу та технології його виготовлення; оволодівають прийомами роботи 3 інструментами, пристосуванням та обладнанням; визначають необхідну кількість матеріалів для виробу. Разом з тим, у них формується уявлення про масштаб та вміння читати й виконувати зображення плоскої деталі (схеми), визначати типи деталей, розрізняти деталі за способом отримання. У процесі такої роботи учень усвідомлює значення деталі як частини виробу, виконує оздоблення виробу за готовою композицію та вчиться захищати свій проект на основі наукових та технічних термінів згідно з технології обробки та виготовлення виробу (деревообробка, металообробка, швейна та харчова промисловість).

Особливої уваги заслуговує те, що завдяки проектуванню учні вчаться залучати для виконання проекту знання 3 інших предметів i практично застосовувати їх (міжпредметний зв'язок). Адже, особливість трудового навчання полягає у поєднанні теоретичних знань $з$ практичним застосуванням. 
Психолого-педагогічні проблеми становлення сучасного фахівця Випуск 2018

Саме на заняттях трудового навчання учитель здійснює розвиток в учнів інтелектуальних, психічних, творчих, моральних, фізичних, соціальних якостей, прагнення до саморозвитку та самоосвіти і підведення випускників до свідомого вибору професій, що істотно прослідковується в оновленій програмі на основі компетентного підходу.

Висновки, перспективи. Таким чином, оновлена навчальна програма 3 трудового навчання для 5-9 класів заснована на компетентнісному та особистісно-орієнтованому підході, що сприяє наближенню процесу трудового навчання до життєвих потреб учня, його інтересів та природних здібностей: програма спрямована на всебічний розвиток особистості учня, формування ключових i предметних компетенцій, де головною предметною компетенцією $\epsilon$ проектно-технологічна, яка забезпечує розвиток технічних здібностей та технологічної грамотності, формування власної потреби в навчанні і спонукає учнів до навчання протягом життя.

За нових умов змінюється організація освітнього процесу на заняттях трудового навчання, яка полягає у побудові навчального процесу залежно від індивідуальної траєкторії розвитку дитини, матеріально-технічної бази майстерні, самостійного розподілу часу на виконання навчального плану, вільного вибору технології виготовлення проекту (разом 3 учнями), застосування інноваційних методів навчання відповідно сучасності, побудові навчального процесу на «педагогіці партнерства», зміною ролі вчителя від єдиного джерела знань на наставника, модератора, наблизивши процес навчання в школі до вміння учнів застосовувати отримані знання в житті.

Перспективи подальших пошуків у напрямі дослідження пов'язані 3 визначенням особливостей використання інших нових педагогічних технологій для формування особистості учня на уроках трудового навчання, зокрема інформаційної, комунікаційної, ціннісносмислової, загальнокультурної, навчально-пізнавальної, соціальнотрудової, компетентності особистісного зростання та ін.

\section{Література}

1. Ключові зміни в оновлених навчальних програмах 5-9 класів (за результатами обговорення на платформі EdEra та у предметних робочих групах) // Трудова підготовка в рідній школі. - 2017. - № 3. C. 2-3.

2. Методичні рекомендації про викладання навчальних предметів у загальноосвітніх навчальних закладах у 2017/2018 навчальному році // Трудова підготовка в рідній школі. - 2017. - № 3. C. 3-22. 
3. Дятленко С. М. Трудове навчання 5-9 класи: практичний посібник для вчителів / С. М. Дятленко, Р. М. Лещук, О. Ю. Медвідь; за заг. ред. А. І. Терещука. - Х. : Ранок, 2017. - 128 с.

4. Концепція «Нова школа. Простір освітніх можливостей» [Електронний ресурс]. - Режим доступу: http://mon.gov.ua/activity/education/zagalna-serednya/ua-sch-2016/.

5. Стешенко В. В. Новій українській школі нове трудове навчання / В.В.Стешенко // Збірник наукових праць Уманського державного педагогічного університету імені Павла Тичини. - 2017. Вип. 1. - С. 350-358.

6. Про освіту: Закон України від 05.09.2017 p. № 2145-VIII / [Електронний ресурс]. http://zakon2.rada.gov.ua/laws/show/2145-19.

7. Гуревич Р. Сучасна парадигма технологічної освіти в школі / Р. Гуревич, В. Бойчук // Трудова підготовка в рідній школі. - 2015. № $6 .-$ C. $2-7$.

8. Методичний супровід викладання трудового навчання в умовах оновленого змісту освіти в 2017/2018 навчальному році: методичні рекомендації / Укл. В. Г. Компанієць. - Миколаїв : ОІППО, $2017-40$ c.

9. Боринець Н. І. Упровадження оновленої програми з трудового навчання для учнів 5-9 класів у 2017-2018 навчальному році / H. I. Боринець [Електронний ресурс] - Режим доступу : http://uploads/editor/12043/660665/sitepaqe 15/files/uprovadzhenia novoji proqramy z trud navch $59 \mathrm{kl}$.pdf.

10. Коберник О. М. Трудове навчання в школі: проектнотехнологічна діяльність. 5-12 класи / За ред. О. М. Коберника, В. В. Беребец, Н. В. Дубова та ін. - Х. : Вид. група «Основа», 2010. $256 \mathrm{c}$.

11. Терещук А. I. Методика організації проектної діяльності старшокласників 3 технології: метод. посіб. для вчителів, навч. прогр., варіат. модулі / А. І. Терещук, С. М. Дятленко. - К. : Літера ЛТД, 2010. $-128 \mathrm{c}$.

Алена Нестеренко. Особенности развития личности ученика на занятиях трудового обучения по обновленной программе 2017 г. Показаны особенности формирования личности ученика на занятиях трудового обучения по обновленной программе 2017 года на основе компетентностного и личностно-ориентированного подхода. Рассмотрено развитие личности ученика на основе 10 ключевых компетентностей, предусмотренных обновленной учебной программой, направленные на формирование жизненной компетентности учащихся. Отмечено ведущей проектно- 
Психолого-педагогічні проблеми становлення сучасного фахівця Випуск 2018

технологической компетентности в трудовом обучении, которая характеризуется способностью ученика применять знания, умения, навыки в прочессе изготовления запланированного проекта. Проанализировань изменения в содержании обновленной учебной программы по трудовому обучению в условиях Новой украинской школь, которые способствуют подготовке выпускника основной школьг к самостоятельности, предприимчивости, инициативности, творчеству, а также саморазвитию и самообучению.

Ключевые слова: личность, личностная направленность обучения, компетентность, трудовое обучение, обновленная учебная программа.

\section{Alyona Nesterenko. Features of development of personality of a apprentsce at labor training according to the updated program of 2017.} The article highlights the peculiarities of formation of the apprentice personality in the occupations of labor education under the updated program of 2017 on the basis of a competent and person-oriented approach. The development of the apprentice personality is based on the 10 key competencies provided by the updated curriculum, which are aimed at forming the vital competency of the apprentice. It is emphasized on the leading design and technological competence in labor training, which is characterized by the ability of the apprentice to apply knowledge, skills, skills in the process of manufacturing a planned project. The changes in the content of the updated educational curriculum on labor education in the conditions of the New Ukrainian school are analyzed, which facilitate the preparation of a graduate of the basic school for autonomy, entrepreneurship, initiative, creativity, self-development and self-education. Keywords: personality orientation of education, competence, labor training, updated educational program.

Стаття надійшла до редакційної колегії: 08.05.2018 Прийнято до друку 09.05.2018

\section{Інформація про автора:}

Нестеренко Альона Сергіївна - аспірант кафедри педагогіки i методики технологічної та професійної освіти, Державний вищий навчальний заклад «Донбаський державний педагогічний університет». 